\title{
A COMPTABILITY STUDY ON DESIGN AND ANALYSIS OF REINFORCED CONCRETE STRUCTURAL DESIGN USING SOFTWARE
}

\author{
Balwinder Lallotra ${ }^{\# 1}$, Dhirendra Singhal $*^{2}$ \\ ${ }^{\# 1}$ Research Scholar I.K. Gujral Punjab Technical University,Jalandhar, India \\ ${ }^{1}$ balwinder.com@gmail.com \\ ${ }^{2}$ Professor and Chairperson, Department of Civil Engineering, \\ D.C.R. University of Science and Technology, Murthal, India \\ 2singhald62@rediffmail.com
}

\begin{abstract}
It has been asserted in literature that the understanding of the software used today is the urgent necessity of the moment in order to match the pace of infrastructural development. This study is undertaken with the objective of checking the comptability of results obtained for the design of basic structural elements of Reinforced Cement Concrete (RCC) using popularly used software STAAD Pro, ETABS and SAP-2000.For this purpose the design results of most commonly used software are validated with manual design by Indian standards to gain the confidence of the users. The basic elements of structures such as beams, column and a simple frame have been discussed. The results for analysis of shear force and bending moment of beams and columns are comparable in all the cases except for the frame when STAAD Pro, ETABS and SAP-2000 are used. For all elements the results obtained from software differed significantly from the results obtained through manual calculations using Kani's method.
\end{abstract}

Keywords- Computations, ETABS, SAP-2000, STAAD Pro, Shear force, bending moment

\section{INTRODUCTION}

The design of a simple building in the earlier times used to take at least a week. However, the design of complicated structures can now be done within a week's time and with more accuracy using a host of software available in the market. Subramanian N. [1] is of the opinion that these software should be regarded as mere tools in the hand of structural engineer. Designer should be aware of any assumptions used and limitations of the programs in the software. Subramanian N. [1] further put the example that some computer programs ignore compression steel when maximum allowable reinforcement in a concrete beam is determined resulting into a larger section. A hard fact which the society faces today is that many of the fresh graduates have not even approached to the design software used in market during their study. Therefore, these engineers have no other option but are bound to blindly accept the results given by the computers. Naghipour-et-al [2] used finite element program ETABS software to find the location of plastic hinge away from the joint location in eccentrically braced frame in 4, 7 and 10 story building. Sharma-et-al [3] studied a 3D framed RC using pushover analysis by increasing the load in small increment till failure with the help of software. They devised failure modes for the beam, column and joint. His study helped the engineers to focus on the weak points of structures to be taken care while designing a structure. Azam and Hosur [4] used ETABS software studied the provision of shear wall placed symmetrically in the building using elastic analysis for strength, stiffness and damping to make building safer.

Attempts have, however, started to verify and gain confidence for the validity of various software. Prashanthet- al [5] compared these software and concluded that area of steel required by using ETABS was less. Hu-et-al [6] studied the response spectrum, time history and linking slab in plan using software SAP-2000, ETABS, MIDAS/GEN and SATWE software for a multistory. He concluded that ETABS is more suitable for regular buildings where as SAP-2000 is more suited to space structures, oblique column and gymnasiums. Al-Tamimiet-al[7] compared the different construction material in three buildings using software ETABS, SAFE and ACI 365 to find the most reliable and beneficial material to be used for the structures. Kumar-et-al [8] studied the building on sloping ground using software ETABS and SAP-2000. They considered seismic forces as per I.S:1893-2002 and stressed the need for proper designing of structure on sloping ground.

Sabeer and Peera [9] compared the results obtained from STAAD Pro and ETABS for a RCC building subjected to lateral and vertical loads and concluded that both software provided different results whereas the difference had not been significant. Rana [10] compared the different aspects of a component design of a building using different software STAAD Pro, STRUDS and ETABS software. He concluded that the ETABS 
gave more economical design than the STAAD Pro and STRUDS. Baral and Yajdani [11] studied five models one with shear wall and four without shear wall using software ETABS to verify how the bending moment, shear force in beam and axial force in the column change by changing the position of the shear walls in the building. Jennifer and Jegidha [12] reviewed the literature of various researchers on the different codes to find which code gives better performance during earthquake. They used software ETABS and SAP-2000 for analysis. He used various codes to find which code gave best results. Leonetti-et-al [13] proposed the efficient treatment of load combination to make the shakedown analysis more affordable tool for practical applications. They used the sap-2000 for analysis. Ramya and Saikumar [14] also compared these software and concluded that area of steel required by using ETABS was less.

Nguyen-et-al [15] studied the fifteen storied building for soil structure interaction on a shallow foundation using ABAQUS software and concluded that the size of the foundation influences the lateral deformation of midsized building which is important information to the design engineers. Ahmed Farghly [16] studied the location of shear wall in 12 storied building using SAP-2000 software which will help the design engineers for better building design. Massumi and Mohammadi [17] devised the evaluation criteria for a seismic behavior of a structure. Gorgun [18] investigated the column beam connection of skeletal structures for stability in semi-rigid frames using computer based method. He pointed out that economies can be achieved by second order (deflection induced) due to reduction in effective length of a column.

Purulekar-et-al [19] studied the seismic performance of a shear wall considering two parameters ultimate load and ultimate drift, verified it analytically and experimentally. They further highlighted the failure pattern, capacity and performance of a shear wall.

This study has been undertaken with the objective that the results obtained from the design software available in the market and generally used for analysis and design of structures by the engineers such as STAAD Pro, SAP-2000 and ETABS confirm theoretical background and various guidelines such as Indian Standards [20-22].

\section{PROBLEM DEFINATION}

In order to achieve above objective, basic elements of structures i.e. beams, column and simple frame were analyzed and designed. These elements were analyzed using all the three software and the results were compared with the manual calculations using Kani's method and IS-456 [20-22]. The details are as under:

\section{A. Fixed Beam}

The prismatic beam of sides $0.3 \mathrm{mx} 0.3 \mathrm{~m}$ and span $7 \mathrm{~m}$ is loaded with uniformly distributed load under fixed end conditions using all the three software ETABS, SAP-2000 and STAAD Pro [23-25].

The results are compared with the manual calculations for the following data.

Size of beam $=0.3 \mathrm{mx} 0.3 \mathrm{~m}$

Span of beam $=7 \mathrm{~m}$

Load $=$ Dead load $+20 \mathrm{kN} / \mathrm{m}$

Grade of concrete: M-20 as per IS: $456-2000$

Grade of Steel: Fe415 as per IS: 1786-2008

$U D L=20 \mathrm{KN} / \mathrm{m}$

A

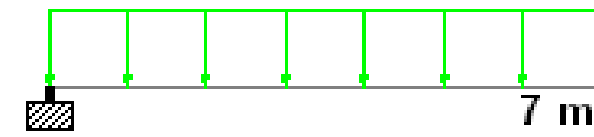

FIXED END

\section{B}

FIXED END

Fig.1 Fixed beam 


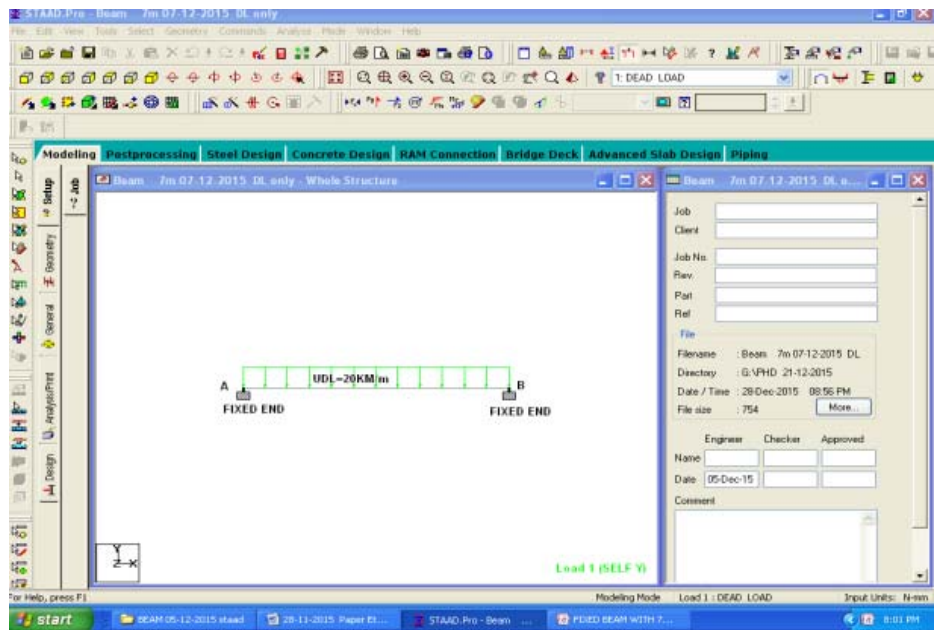

Fig.2 Beam analysis by software

\section{B. Column with point load}

The column of $0.3 \mathrm{mx} 0.3 \mathrm{~m}$ of length $3.5 \mathrm{~m}$ is considered. The column is loaded with axial vertical load on top and fixed at the bottom end. The results are compared with the manual calculations for the following data.

Size of Column $=0.3 \mathrm{mx} 0.3 \mathrm{~m}$

Load $=$ Dead load $=500 \mathrm{kN}$

Length of Column $=3.5 \mathrm{~m}$

Grade of concrete: M-20 as per IS: $456-2000$

Grade of Steel: Fe415 as per IS: 1786-2008

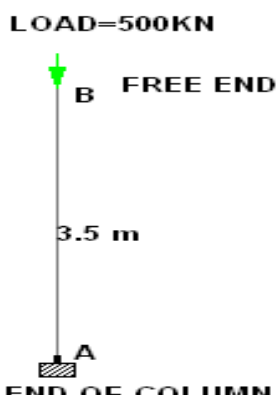

FIXED END OF COLUMN

Fig.3 Column with one end fixed other free

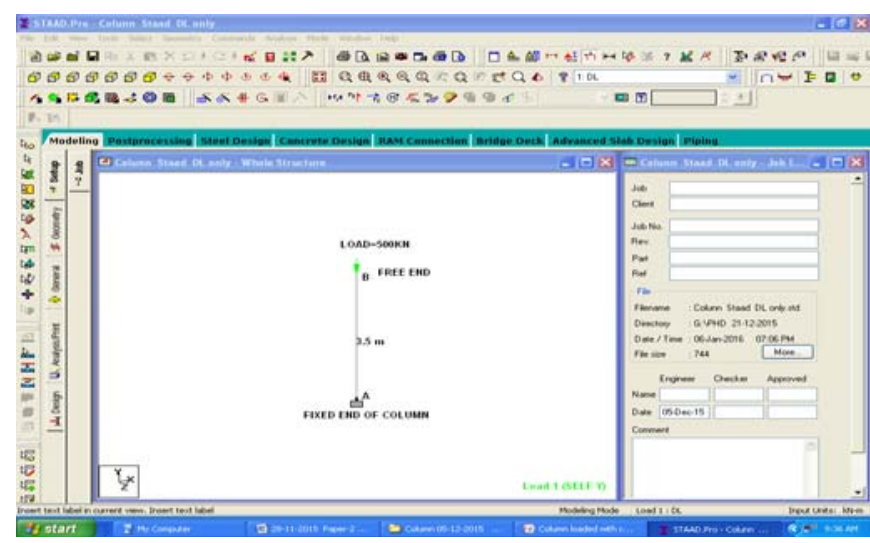

Fig.4 Column analysis by software 


\section{Cantilever beam}

The prismatic cantilever beam of size $0.3 \mathrm{mx} 0.3 \mathrm{~m}$ with one end 'A' fixed and free end 'B' of span $7 \mathrm{~m}$ is loaded with concentrated load at free end .The structure is analyzed using all the three software ETABS, SAP-2000 and STAAD Pro. [20-22] and results are compared with the manual calculations for the following data.

Size of cantilever beam $=0.3 \mathrm{mx} 0.3 \mathrm{~m}$

Length of cantilever beam $=7 \mathrm{~m}$

Load $=$ Dead Load $+10 \mathrm{kN}$ at free end

Grade of concrete: M-20 as per IS: 456-2000

Grade of Steel: Fe415 as per IS: 1786-2008

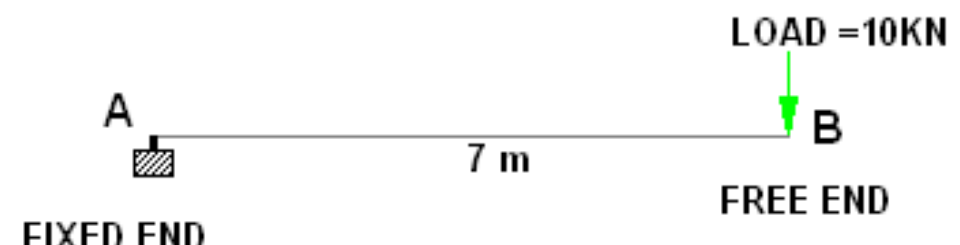

FIXED END

Fig.5 Cantilever Beam loaded at free end

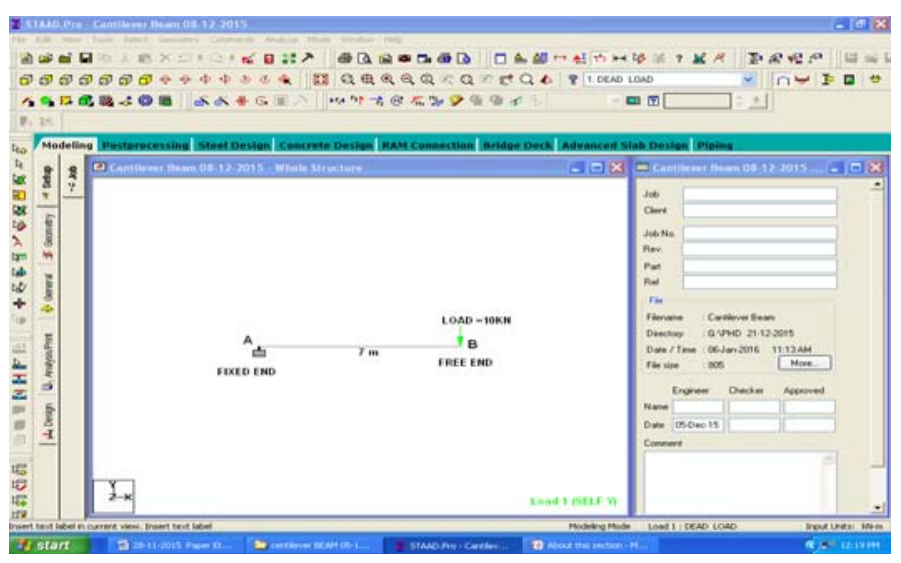

Fig. 6 Cantilever beam analysis by software

\section{Portal frame}

A portal frame with beam size $0.3 \mathrm{~m} \times 0.3 \mathrm{~m}$ and column size $0.3 \mathrm{~m} \times 0.3 \mathrm{~m}$ having concentrated load on one span and uniformly distributed load on the other span as shown in the Figure7 is considered. Modeling and analysis of the structure are done separately using software ETABS, SAP-2000 and STAAD Pro. [20-22].The results obtained are compared with manual calculations using Kani's method for the following data.

Length of Beam $\mathrm{AD}=2 \mathrm{~m}$

Length of Beam $\mathrm{DB}=4 \mathrm{~m}$

Height of Column $=4 \mathrm{~m}$

Size of Beam AD=300mm x 300mm

Size of Beam DB=300mm x 300mm

Size of Column CD $=300 \mathrm{~mm} \times 300 \mathrm{~mm}$

Grade of concrete: $\mathrm{M}-20$ as per IS:456 $=2000$

Grade of Steel: Fe415 as per IS: $1786=2008$ 

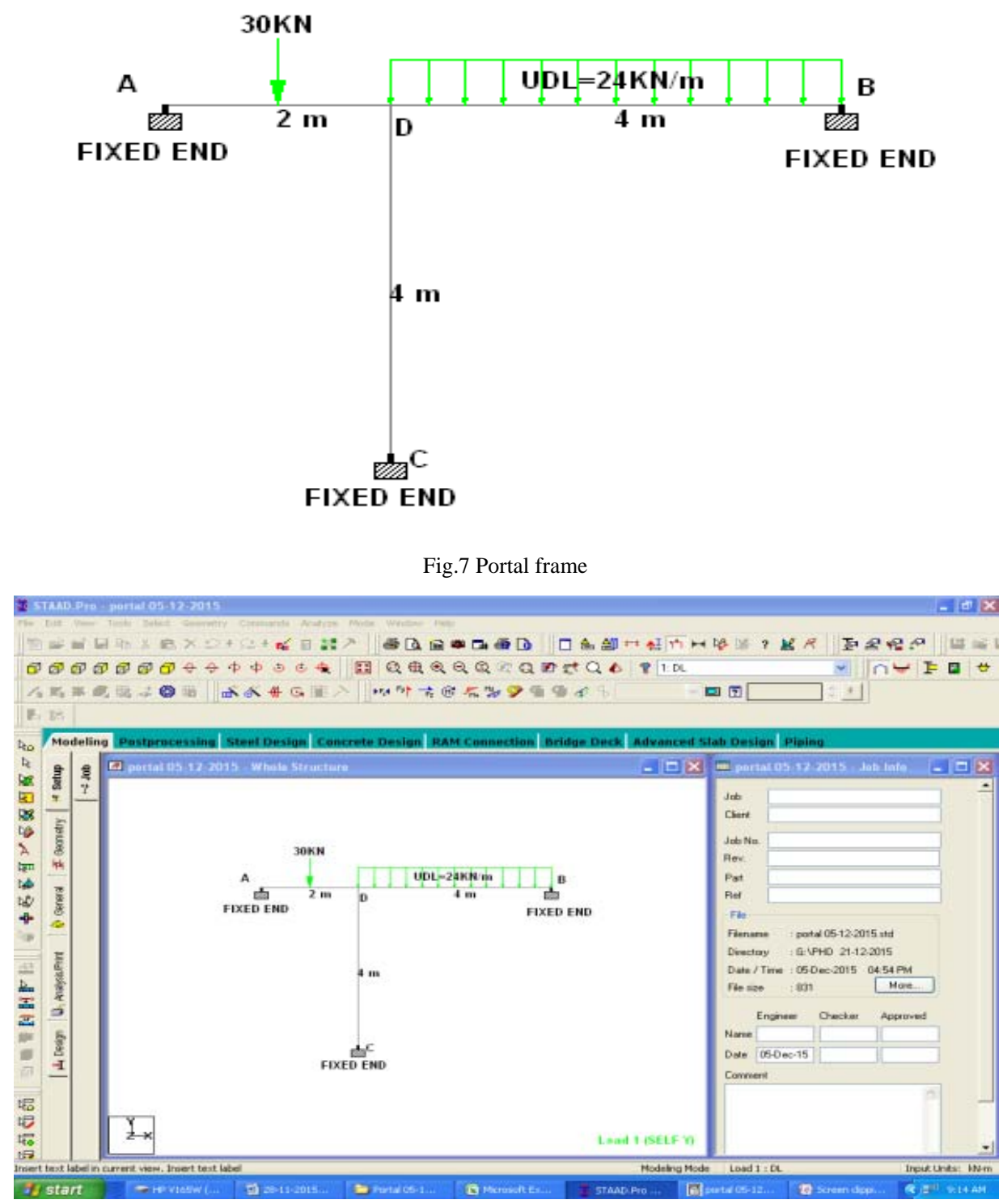

Fig.8 Portal frame analysis by software

\section{RESULTS AND DISCUSSION}

Results as obtained from ETABS, SAP-2000 and STAAD Pro [20-22] and from Kani's method are presented below and have been discussed further.

\section{A. Fixed Beam Results}

The results output of a sample beam for all the three software ETABS, SAP-2000 and STAAD Pro. Obtained have been tabulated. Table 1 is for the bending moment at five different locations i.e. at end A, 1/4L,1/2L,3/4L and end $\mathrm{B}$.

Table-1 Comparison of Bending Moment results for fixed beam.

\begin{tabular}{|c|c|c|c|c|c|}
\hline $\begin{array}{c}\text { OUTPUT } \\
\text { TYPE }\end{array}$ & LOCATION & STAAD Pro & ETABS & SAP-2000 & $\begin{array}{c}\text { THORETICAL VALUE } \\
\text { (Manual Calculation) }\end{array}$ \\
\hline \multirow{3}{*}{$\begin{array}{c}\text { Bending } \\
\text { Moment } \\
(\mathrm{KN}-\mathrm{m})\end{array}$} & End 'A' & -135.489 & -135.489 & -136.278 & -137.813 \\
\cline { 2 - 6 } & $1 / 4$ point & -16.937 & -15.899 & -15.992 & -17.036 \\
\cline { 2 - 6 } & $1 / 2$ point & -67.745 & -67.704 & -68.139 & -68.907 \\
\cline { 2 - 6 } & $3 / 4$ point & -16.937 & -15.899 & -15.992 & -17.036 \\
\cline { 2 - 6 } & End 'B' & -135.489 & -135.489 & -136.278 & -137.813 \\
\hline
\end{tabular}


Table 2 shows the shear force at five different locations i.e. at end A, 1/4L, 1/2L, 3/4L and end B.

Table-2Comparison of Shear Force results for fixed beam.

\begin{tabular}{|c|c|c|c|c|c|}
\hline $\begin{array}{c}\text { OUTPUT } \\
\text { TYPE }\end{array}$ & LOCATION & STAAD Pro & ETABS & SAP-2000 & $\begin{array}{c}\text { THEORETICAL VALUE } \\
\text { (Manual Calculation) }\end{array}$ \\
\hline \multirow{3}{*}{$\begin{array}{c}\text { Shear } \\
\text { Force } \\
(\mathrm{KN})\end{array}$} & End 'A' & -116.133 & -116.130 & -116.810 & -118.125 \\
\cline { 2 - 6 } & $1 / 4$ point & -58.067 & -58.065 & -58.404 & -58.407 \\
\cline { 2 - 6 } & $1 / 2$ point & 0 & 0 & $1.71 \mathrm{E}-13$ & 0 \\
\cline { 2 - 6 } & End 'B' & -58.067 & -58.065 & -58.404 & -58.407 \\
\cline { 2 - 6 } & & -116.133 & -116.130 & -116.810 & -118.125 \\
\hline
\end{tabular}

The tensile and compressive steel obtained are for the fixed beam for all the three software and with the theoretical value calculated with from SP-16 have been shown in Table 3.

Table-3 Comparison of tensile and compressive steel for fixed beam.

\begin{tabular}{|c|c|c|c|c|}
\hline OUTPUT TYPE & $\begin{array}{c}\text { STAAD } \\
\text { Pro }\end{array}$ & ETABS & SAP-2000 & $\begin{array}{c}\text { THEORETICAL VALUE } \\
\text { (Calculation by SP-16) }\end{array}$ \\
\hline Factored B.M. $(\mathrm{KN}-\mathrm{m})$ & -135.489 & -135.489 & -136.278 & -137.813 \\
\hline Tensile steel $\mathrm{A}_{\mathrm{st}}\left(\mathrm{mm}^{2}\right)$ & 1073.54 & 825 & 851 & 885.225 \\
\hline Compressive SteelA ${ }_{\mathrm{sc}}\left(\mathrm{mm}^{2}\right)$ & 1760.46 & 1598 & 1606 & 1630.150 \\
\hline Total Area of Steel $\left(\mathrm{mm}^{2}\right)$ & 2833.54 & 2423 & 2457 & 2515.375 \\
\hline
\end{tabular}

\section{B. Column Results}

The result obtained for the column for all the three software ETABS, SAP-2000 and STAAD Pro. [20-22] have been tabulated in Table 4 .

Table-4 Comparison of results for Steel in Column

\begin{tabular}{|l|l|c|c|c|}
\hline OUTPUT TYPE & STAAD Pro & ETABS & SAP-2000 & THEORETICAL VALUE \\
\hline $\begin{array}{l}\text { Steel } \\
\text { Quantity }\left(\mathrm{mm}^{2}\right)\end{array}$ & $682.63\left(\mathrm{~mm}^{2}\right)$ & $787\left(\mathrm{~mm}^{2}\right)$ & $720\left(\mathrm{~mm}^{2}\right)$ & $720\left(\mathrm{~mm}^{2}\right)$ \\
\hline
\end{tabular}

Table 5 shows the comparison of quantity of concrete given by all three software ETABS, SAP-2000 and STAAD Pro along with theoretical values

Table-5 Comparison of results for concrete quantity.

\begin{tabular}{|l|c|c|c|c|}
\hline OUTPUT TYPE & STAAD Pro & ETABS & SAP-2000 & THEORETICAL VALUE \\
\hline $\begin{array}{l}\text { Concrete } \\
\text { Quantity }\left(\mathrm{m}^{3}\right)\end{array}$ & 0.32 & 0.315 & 0.315 & 0.315 \\
\hline
\end{tabular}

\section{Cantilever Beam Results}

The results obtained for a simple cantilever beam for all the three software ETABS, SAP-2000 and STAAD Pro. [20-22] are tabulated. Table 6 shows the bending moment at five different locations i.e. at end A, 1/4L, 1/2L, 3/4L and end $\mathrm{B}$.

Table-6 Comparison of results for cantilever beam for bending moment.

\begin{tabular}{|c|c|c|c|c|c|}
\hline OUTPUT TYPE & LOCATION & STAAD Pro & ETABS & SAP-2000 & $\begin{array}{c}\text { THEORETICAL } \\
\text { VALUE }\end{array}$ \\
\hline \multirow{3}{*}{$\begin{array}{c}\text { Bending Moment } \\
(\mathrm{KN}-\mathrm{m})\end{array}$} & Fixed End 'A' & -182.93 & -182.92 & -187.66 & -187.69 \\
\cline { 2 - 6 } & $1 / 4$ point & -122.586 & -122.685 & -125.353 & -125.261 \\
\cline { 2 - 6 } & $1 / 2$ point & -71.98 & -71.98 & -73.17 & -73.17 \\
\cline { 2 - 6 } & 3/4 point & -31.1205 & -31.2195 & -31.5225 & -31.418 \\
\cline { 2 - 6 } & Free End 'B' & 0 & 0 & $7.41 \mathrm{E}-14$ & 0 \\
\hline
\end{tabular}

Table 7 shows the shear force of a cantilever beam at five different locations i.e. at end A, 1/4L, 1/2L, 3/4L and end $\mathrm{B}$. 
Table-7 Comparison of shear force results for cantilever beam.

\begin{tabular}{|c|c|c|c|c|c|}
\hline $\begin{array}{c}\text { OUTPUT } \\
\text { TYPE }\end{array}$ & LOCATION & STAAD Pro & ETABS & SAP-2000 & $\begin{array}{c}\text { THEORETICAL } \\
\text { VALUE }\end{array}$ \\
\hline \multirow{3}{*}{$\begin{array}{c}\text { Shear Force } \\
(\mathrm{KN})\end{array}$} & Fixed End 'A' & -37.266 & -37.260 & -38.618 & -38.625 \\
\cline { 2 - 5 } & $1 / 4$ point & -31.699 & -31.695 & -32.713 & -32.730 \\
\cline { 2 - 5 } & $1 / 2$ point & -26.133 & -26.130 & -26.809 & -26.730 \\
\cline { 2 - 5 } & 3/4 point & -20.566 & -20.565 & -20.904 & -20.905 \\
\cline { 2 - 5 } & Free End 'B' & -15 & -15 & -15 & -15 \\
\hline
\end{tabular}

In Table 8 steel has been compared for the cantilever beam thorough all the three software ETABS, SAP-2000 and STAAD Pro. with the theoretical value calculated as per I.S. code-2000.

Table-8 Comparison of results for cantilever beam for steel.

\begin{tabular}{|c|c|c|c|c|c|}
\hline $\begin{array}{c}\text { OUTPUT } \\
\text { TYPE }\end{array}$ & AREA OF STEEL & $\begin{array}{l}\text { STAAD } \\
\text { Pro }\end{array}$ & ETABS & SAP-2000 & $\begin{array}{c}\text { THEORETICAL } \\
\text { VALUE }\end{array}$ \\
\hline \multirow{4}{*}{$\begin{array}{c}\text { Steel } \\
\text { By Software }\end{array}$} & Factored B.M. $(\mathrm{kNm})$ & -182.930 & -182.930 & -187.664 & -187.688 \\
\cline { 2 - 6 } & $\mathrm{A}_{\mathrm{st}\left(\mathrm{mm}^{2}\right)}$ & 2316.96 & 2123 & $3216(\mathrm{O} / \mathrm{S})^{*}$ & - \\
\cline { 2 - 6 } & $\begin{array}{c}\mathrm{A}_{\mathrm{sc}}\left(\mathrm{mm}^{2}\right) \\
\text { Total Area of Steel } \\
\left(\mathrm{mm}^{2}\right)\end{array}$ & 3953.32 & 3485 & 5693 & - \\
\hline
\end{tabular}

$(\mathrm{O} / \mathrm{S})^{*}$-Indicates that element is overstressed.

\section{Portal Frame Results}

The results obtained for a simple portal frame from ETABS, SAP-2000 and STAAD Pro. [20-22] are tabulated in Table 9.

Table-9 Comparison of bending moment results for portal frame.

\begin{tabular}{|c|c|c|c|c|c|c|}
\hline $\begin{array}{l}\text { OUTPUT } \\
\text { TYPE }\end{array}$ & BEAM & LOCATION & $\begin{array}{l}\text { STAAD } \\
\text { Pro }\end{array}$ & ETABS & SAP-2000 & $\begin{array}{l}\text { THEORETICAL VALUE } \\
\text { (Kani's Method) }\end{array}$ \\
\hline \multirow{6}{*}{$\begin{array}{c}\text { Bending } \\
\text { Moment } \\
\mathrm{M}_{\mathrm{z}} \\
(\mathrm{KN}-\mathrm{m})\end{array}$} & \multirow[b]{2}{*}{$\mathrm{AD}$} & A & 7.290 & 7.040 & 7.093 & 2.063 \\
\hline & & $\mathrm{D}$ & 28.808 & 28.799 & 28.934 & 29.625 \\
\hline & \multirow[b]{2}{*}{$\mathrm{BD}$} & B & 59.007 & 59.006 & 59.302 & 9.188 \\
\hline & & $\mathrm{D}$ & 39.872 & 39.867 & 40.057 & 38.813 \\
\hline & \multirow[b]{2}{*}{ CD } & $\mathrm{C}$ & 5.460 & 5.459 & 5.488 & 4.593 \\
\hline & & $\mathrm{D}$ & 11.064 & $9.825^{\$}$ & 11.126 & 9.186 \\
\hline
\end{tabular}

\$-9.825 -Value taken at effective depth of beam face for column.

In Table 10 the steel has been compared for the simple portal frame for all the three software ETABS, SAP-2000 and STAAD Pro. with the theoretical value (IS-456:2000).

Table-10 Comparison of steel results of portal frame.

\begin{tabular}{|c|c|c|c|c|c|}
\hline ELEMENT & AREA OF STEEL & STAAD Pro & ETABS & SAP-2000 & $\begin{array}{c}\text { THEORETICAL } \\
\text { VALUE }\end{array}$ \\
\hline \multirow{4}{*}{$\begin{array}{c}\text { AD } \\
\text { (Beam) }\end{array}$} & Max. Factored B.M.(KN-m) & 28.808 & 28.799 & 28.934 & 29.625 \\
\hline & $\mathrm{A}_{\mathrm{st}\left(\mathrm{mm}^{2}\right)}$ & 165.29 & 233 & 233 & 420.79 \\
\hline & $\left.\mathrm{A}_{\mathrm{sc}} \mathrm{mm}^{2}\right)$ & 359.42 & 251 & 317 & Nil \\
\hline & Total Area of Steel $\left(\mathrm{mm}^{2}\right)$ & 524.71 & 484 & 550 & 420.79 \\
\hline \multirow{4}{*}{$\begin{array}{c}\text { BD } \\
\text { (Beam) }\end{array}$} & Max. Factored B.M.(KN-m) & 59.007 & 59.01 & 59.302 & 38.813 \\
\hline & $\mathrm{A}_{\mathrm{st}\left(\mathrm{mm}^{2}\right)}$ & 331.50 & 365 & 468 & 715.37 \\
\hline & $\left.\mathrm{A}_{\mathrm{sc}(} \mathrm{mm}^{2}\right)$ & 781.24 & 731 & 736 & Nil \\
\hline & Total Area of Steel $\left(\mathrm{mm}^{2}\right)$ & 1112.74 & 1096 & 1204 & 715.37 \\
\hline \multirow{2}{*}{$\begin{array}{c}\text { CD } \\
\text { (Column) }\end{array}$} & Max. Factored B.M.(KN-m) & 7.376 & 6.55 & 7.417 & 9.186 \\
\hline & $\mathrm{A}_{\mathrm{C}\left(\mathrm{mm}^{2}\right)}$ & 452.93 & 720 & 720 & $720(\min 0.8 \%)$ \\
\hline
\end{tabular}


Table 11 compares the bending moment output of all the three software ETABS, SAP-2000 and STAAD Pro. with the theoretical value calculated by Kani’s methods at the mid points of a portal frame.

Table-11 Comparison of results of bending moment for beams at mid span for portal frame.

\begin{tabular}{|c|c|c|c|c|c|}
\hline $\begin{array}{c}\text { OUTPUT } \\
\text { TYPE }\end{array}$ & BEAM & LOCATION & STAAD PRO & ETABS & SAP-2000 \\
\hline \multirow{2}{*}{$\begin{array}{c}\text { Bending } \\
\text { Moment Mz } \\
(\text { KN-m) }\end{array}$} & BD & Mid Point & -6.177 & -6.171 & -6.174 \\
\cline { 2 - 6 } & CD & Mid Point & -28.923 & -28.328 & -29.068 \\
\hline
\end{tabular}

Table 12 compares the reaction of a simple portal frame given by three software ETABS, SAP-2000 and STAAD Pro. along three axis $\mathrm{X}, \mathrm{Y}, \mathrm{Z}$.

Table-12 Comparison of reactions for portal frame at support.

\begin{tabular}{|c|c|c|c|c|c|}
\hline LOCATION & DIRECTION & STAAD Pro & ETABS & SAP-2000 & $\begin{array}{l}\text { THEORETICAL } \\
\text { VALUE }\end{array}$ \\
\hline \multirow{3}{*}{$\begin{array}{l}\text { Reactions } \\
\text { At Fixed } \\
\text { Support 'A' } \\
\text { (N) }\end{array}$} & $\mathrm{x}$ & -1836.021 & -1836.46 & -1845.91 & 1147.50 \\
\hline & $\mathrm{y}$ & 9858.397 & 9867.39 & 9969.77 & 23550 \\
\hline & $\mathrm{z}$ & 378.737 & 0 & 0 & 0 \\
\hline \multirow{3}{*}{$\begin{array}{l}\text { Reactions } \\
\text { At Fixed } \\
\text { Support 'B' } \\
(\mathrm{N}) \\
\end{array}$} & $\mathrm{x}$ & 918.011 & 918.23 & 922.95 & 1147.50 \\
\hline & $\mathrm{y}$ & 55430.470 & 55430.48 & 55706.16 & 64605 \\
\hline & $\mathrm{z}$ & 125.521 & 0 & 0 & 0 \\
\hline \multirow{3}{*}{$\begin{array}{l}\text { Reactions } \\
\text { At Fixed } \\
\text { Support 'C' } \\
\text { (N) }\end{array}$} & $\mathrm{x}$ & 2754.032 & 2754.70 & 2768.86 & 1147.50 \\
\hline & $\mathrm{y}$ & 81916.558 & 81906.13 & 82817.42 & 79405.50 \\
\hline & $\mathrm{z}$ & 504.258 & 0 & 0 & 0 \\
\hline
\end{tabular}

\section{DISCUSSION}

The results obtained after the analysis for the four different basic structural elements beam, column, cantilever beam and portal frame are discussed in sections 4.1, 4.2, 4.3 and 4.4 below.

\section{A. Fixed Beam}

The results obtained for design of fixed beam have been shown in Table (1-3). It was observed that there was no significant difference in analysis for bending moment and shear force for all the cases. The value of steel required as obtained from ETAB, SAP-2000 and Kani's method hardly differ by $10 \%$. However, the steel required as obtained by STAAD Pro differs significantly by more than $10 \%$ as compared to the steel requirement obtained by Kani's method. The amount of reinforcement as obtained by STAAD Pro is more than what is required by a balanced section. Hence, this violates the basic philosophy of limit state design [20] by producing an over reinforced section.

\section{B. Column}

The results obtained for design of the column have been shown in Table (4-5).The analysis shows that there is no significant difference in the quantity of steel and concrete for all the cases. The values of steel given by SAP2000 are exactly same compared to theoretical methods and the results of ETABS are hardly different by $10 \%$. The amount of reinforcement given by STAAD Pro is less than minimum required ( $0.8 \%$ of cross-section as per I.S. code). It is again violates the requirements of IS: $456-2000$ [20].

\section{Cantilever Beam}

The results obtained for design of a cantilever beam for has been shown in Tables (6-8). It is clear from the table values that there is no significant difference in the analysis and variation is less than $10 \%$. Table 8 shows the values of steel for a cantilever beam with different software and theoretical value as per Indian Standard requirements. Steel area given by SAP-2000 is highest and the software shows that the beam is also overstressed [23]. STAAD Pro shows $13.42 \%$ more steel as compared to ETABS although the moments given by 
both the software is same. However the section of beam is over reinforced and cannot be designed as per IS456:2000 Code [20]. Therefore, it is observed that the beam section designed using different software had been over-reinforced and therefore basic inherent advantage of limit state design is not met.

\section{Portal Frame}

The bending moment for the portal frame given in Table $\mathbf{9}$ shows the variation at the fixed ends A and B as compared to the theoretical values of bending moment. The variation of bending moment at the fixed end $\mathrm{A}$ is 253.36\%, 241.25\%, 243.82\%, respectively, for STAAD Pro, ETABS and SAP-2000 software compared to theoretical value. The variation of bending moment at the fixed end B is $542.21 \%, 542.21 \%, 545.43 \%$, respectively, for STAAD Pro, ETABS and SAP-2000 software compared to theoretical value. This is due to change in the rigidity of the joint at the end of the beam making it unstable due to instability conditions at the ends providing degree of freedom in one or more direction $\left(\mathrm{F}_{\mathrm{x}}, \mathrm{F}_{\mathrm{y}}, \mathrm{F}_{\mathrm{z}}\right.$ and $\left.\mathrm{M}_{\mathrm{x}}\right)$ [23,25]. The values in ETABS show the variation on the account that these values are given at the effective depth from the face of the beam. Table 10 shows steel provided in beam AD for all the three software STAAD Pro, ETABS and SAP-2000 which is $24.70 \%, 15.02 \%, 30.95 \%$ respectively, more than the theoretical results though the bending moment given by all the three software is almost same (Table 11). Also, in case of beam BD, the steel determined by STAAD Pro, ETABS and SAP-2000, respectively, are $55.55 \%, 53.21 \%$ and $68.30 \%$ more as compared to the theoretical value. The design results of column matches with the theoretical value for ETABS and SAP software but the value of steel given by STAAD Pro is less than the permissible limit (0.8\%) (IS-456; 2000) [20] specified by the IS-456 Code .Table 12 shows the values of reactions given by STAAD Pro, ETABS and SAP-2000 software. It is observed that there is insignificant variation along $\mathrm{X}$-axis and Y-axis but there is a significant variation of force along Z-axis because of more degree of freedom provided by instability condition [23, 25]. There is no significant variation in the values of ETABS and SAP-2000 but the variation is significant along ' $\mathrm{Z}$ ' direction for STAAD Pro at the joint 'A', joint 'B' and joint ' $C$ '.

\section{CONCLUSIONS}

- The comparison of analysis of force for the fixed and cantilever beams is closer to the theoretical value in case of SAP-2000. Moment in STAAD Pro and ETABS is on the lower side.

- The quantity of concrete provided for a fixed beam given by all the three software is same as that of theoretical value.

- The software provided required amount of steel in reinforced cantilever beam although the cantilever beam cannot be designed theoretically as under reinforced section using Indian Standards.

- There is no significant variation of shear force given by STAAD Pro, ETABS and SAP-2000 compared to theoretical value for the cantilever beam

- The fixed end moment in case of a portal frame showed significant variation at the fixed ends of a frame but the variation at continuous supports are within $5 \%$ compared to theoretical value.

- The area of steel results for ETABS and SAP-2000 exactly matches the theoretical value of steel in case of portal frame but the steel results given by STAAD Pro are less than minimum recommended by I.S. code.

- The results reactions at the supports for STAAD Pro, ETABS and SAP-2000 are almost same along Xdirection and Y-direction but there is a huge variation along Z-axis on the account of instability condition in the joint.

All the three software STAAD Pro, ETABS and SAP-2000 give good approximation of the results for bending moments, shear forces, axial forces with the independent results designed manually for the same problem [2025]. The area of steel shows a large variation of order of more than $5 \%$ even for the same moments. It is therefore concluded that more expertise is required to a Civil Engineer when more complicated structures are designed.

\section{REFERENCES}

[1] Subramanian N, Are our structural engineers geared up for the challenges of the profession? The Indian Concrete Journal, Vol.1, pp. 20-26, 2011.

[2] Naghipour M, Javadi N and Nagipour A, "Investigation of RBS connection ductility in eccentrically braced frame”, Procedia Engineering, Vol.14, pp. 473-752, 2011.

[3] Sharma A, Reddy G.R, Eligehausen, R. and Vaze K.K, "Experimental and analytical investigation on seismic behavior of RC framed structure by pushover method”, Structure Engineering And Mechanics, Vol. 39, No.1, pp.125-145, 2011.

[4] Azam S.K and Hosur V, "Seismic performance evaluation of multistoried RC framed buildings with shear with shear wall", International Journal of Scientific Engineering Research, Vol. 4, No.1, pp.1-6, 2013.

[5] Prasanth P, Anshuman S, Pandey R.K and Herert A, "Comparison of design results of a structure designed using STAAD and ETAB Software”. International Journal of Civil and Structural Engineering, Vol.2, No. 3, pp. 860-875, 2012.

[6] Hu K. Yang Y, Mu S and Qu G, "Study on High-rise Structure with Oblique Columns by ETABS, SAP-2000, MIDAS/GEN and STAVE”, Procedia Engineering, Vol 31, pp.474-480, 2012.

[7] Al-Tamimi A.K, Ibrahim A and Al-Sughaiyer N. Evaluation of suitability of multistory reinforced concrete structure”, Physics Procedia, Vol. 55, pp.445-450, 2014. 
[8] Kumar S, Garg V and Sharma A, "Effect of sloping ground on structural performance of RCC building under seismic load", International Journal of Science Engineering and Technology, Vol. 2,pp.1310-1320, 2014.

[9] Sabeer M and Peera D.G, "Comparison design result of RCC buildings using STAAD and ETABS software". International Journal of Innovative Research in Advanced Engineering, Vol. 2, pp.92-97, 2015.

[10] Rana Y.R, "Comparison of analysis and design results of a structural elements using STAAD Pro, STRUDS, and ETABS software", International Journal of Scientific Progress and Research, Vol14, pp. 50-52, 2015.

[11] Baral A and Yajdani S.K, "Seismic analysis of RC framed building for different position of shear wall", International Journal of Innovative Research In Science, Engineering and Technology, Vol. 4, No5, pp.3346-3353, 2015.

[12] Jennifer P. and Jegidha KJ. (2015), "Review of seismic design of multistoried RC building using various codes". International Journal of Innovative Research in Science, Engineering and Technology, Vol.2, pp.44-46, 2015.

[13] Leonetti L, Casciaro R and Garcea G, "Effective treatment of complex statical and dynamical load combinations with shakedown analysis of 3D frame”, Elsevier computers and structures,Vol.158, pp.124-139, 2015.

[14] Ramya D and Saikumar A. V. S, "Comparative study on design and analysis of multistoried building (G+10) by STAAD Pro and ETABS software”, International Journal of Engineering Sciences and Research Technology, Vol.4,pp.125-130, 2015.

[15] Van Nguyen Q, Fatahi B and Hokmabadi A.S, "The effect of foundation size on the seismic performance of buildings considering the soil structure-foundation-structure interaction”, Structure Engineering And Mechanics, Vol. 58, No.6, pp.1045-1075, 2016.

[16] Farghly A. A, " Seismic assessment of slender high rise buildings with different shear Configurations”, Advances in Computational Design, Vol.1, No.3, pp.221-234, 2016.

[17] Massumi A and Mohammadi R, "Structural redundancy of 3D RC frames under seismic excitations", Structure Engineering And Mechanics, Vol.9, No.1, pp.15-36, 2016.

[18] Gorgun H, "The stability of semi-rigid skeletal structures accounting for shear Deformation", Structure Engineering And Mechanics, Vol.57, No.6,pp.1065-1084, 2016.

[19] Parulekar Y.M, Reddy G.R, Singh R.K, Gopalkrishnan N and Ramarao G.V, "Seismic performance evaluation of mid-rise shear walls: experimental and analysis”, Structure Engineering and Mechanics, Vol. 59, pp.291-312, 2016.

[20] Standard I. Plain and Reinforced Concrete-Code of Practice (IS-456:2000).Bureau of Indian Standards, New Delhi, July2000.

[21] Bureau of Indian Standards(IS1893), Part-1: Criteria for Earthquake Resistant Design of Structures: General Provisions and Buildings.

[22] Bureau of Indian Standard(IS 1786):High Strength Deformed Bars and Wires Concrete Reinforcement, New Delhi, India, 2008.

[23] Wilson E.L. and Habibulah A., "SAP2000 integrated finite element analysis and design of structures, Analysis reference, Computers and Structures, 1997.

[24] STAAD PRO V8i. (2012):Technical Reference Manual Bentley, 2012.

[25] ETABS (version 9): ETABS user’s manual.CSI.

\section{AUTHOR PROFILE}

Er. Balwinder Lallotra is a research scholar at PTU, Jalandhar, India and working at M. M. University at Ambala as an Associate Professor. He has about 20 years experience both in consultancy relates to structural design and teaching. The other interests of author are computer aided design, remote sensing and GIS.

Dr Dhirendra Singhal is a professor and Chairperson in department of civil engineering at D.C.R. University of Science and Technology, Murthal, India He has number of papers to his credit . He is a member of various technical organisations and associated with various research projects. 